Published by LPMP Imperium

Journal homepage: https:/ / ejournal.imperiuminstitute.org/ index.php/ AKURASI

\title{
Pengaruh Gaya Hidup dan Literasi Keuangan Terhadap Pengelolaan Keuangan Tenaga Kerja Muda di Jakarta
}

\author{
Nurul Amalia Putri*, Diyan Lestari \\ Manajemen, Fakultas Bisnis, Institut Teknologi dan Bisnis Kalbis
}

\begin{abstract}
The main purpose of this research is to analyze the impact of lifestyle and financial literacy on financial management. The method of this research is quantitative research. The population of this research is young workers in Jakarta with accidental sampling techniques using 30 samples as a pre-test and 135 samples as the main test. The analysis techniques use multiple regression, $\mathrm{t}$-test, and the $\mathrm{F}$ test. The result of $\mathrm{t}$-test showed that lifestyle and financial literacy partially affected on financial management. And the result of the $\mathrm{F}$ test showed that lifestyle and financial literacy simultaneous affected on financial management.
\end{abstract}

Keywords lifestyle, financial literacy, financial management

\begin{abstract}
Abstrak
Tujuan utama dari penelitian ini adalah untuk menganalisis dampak gaya hidup dan literasi keuangan pada manajemen keuangan. Metode penelitian ini adalah penelitian kuantitatif. Populasi penelitian ini adalah pekerja muda di Jakarta dengan teknik sampling aksidental menggunakan 30 sampel sebagai pre-test dan 135 sampel sebagai tes utama. Teknik analisis menggunakan regresi berganda, uji-t, dan uji F. Hasil uji-t menunjukkan bahwa gaya hidup dan literasi keuangan berpengaruh secara parsial terhadap manajemen keuangan. Dan hasil uji $F$ menunjukkan bahwa gaya hidup dan literasi keuangan secara simultan mempengaruhi manajemen keuangan.
\end{abstract}

Kata kunci gaya hidup, literasi keuangan, manajemen keuangan

$\bigotimes$ Email korespondensi: nurulameliaputri@gmail.com

Pedoman Sitasi: Nurul Amalia Putri \& Diyan Lestari (2019).Pengaruh Gaya Hidup dan Literasi Keuangan Terhadap Pengelolaan Keuangan Tenaga Kerja Muda Di Jakarta. AKURASI, 1(1), 31 - 42
AKURASI

Paper type

Research paper

Received: 20 Mar 2019

Accepted: 15 Jun 2019

Online: 1 Jul 2019

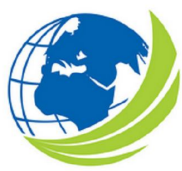

Akurasi: Jurnal Riset Akuntansi dan Keuangan, Vol 1, No.1, Agustus 2019, pp. 31 - 42

eISSN 2685-2888 


\section{PENDAHULUAN}

Perlambatan konsumsi di masyakarat saat ini menunjukkan bahwa telah terjadi penurunan daya beli masyarakat yang dampaknya akan mempengaruhi pertumbuhan ekonomi secara keseluruhan. Menurut Tedy dkk (2002 : 210) konsumsi merupakan hal yang sangat penting untuk analisis ekonomi jangka panjang dan pendek. Hal ini karena konsumsi agregat yang merupakan penjumlahan dari pengeluaran seluruh rumah tangga yang ada dalam perekonomian dan merupakan komponen terpenting karena kontribusinya pada Gross Domestic Product (GDP) yang mencapai 50-60\%. Dengan adanya perubahan konsumsi pada masyarakat maka tingkat keseimbangan pendapatan akan berubah pula.

Berdasarkan riset yang dilakukan Nielsen, pertumbuhan penjualan ritel sepanjang lebaran tahun 2017 hanya mencapai 5\% di mana persentase tersebut merupakan persentase yang paling rendah dalam lima tahun terakhir. Berdasarkan data tersebut dapat disimpulkan bahwa adanya penurunan yang cukup besar dari penjualan ritel di Indonesia khusunya untuk barang konsumsi kemasan seperti mie instan, susu, kopi dan produk makanan lainnya (Agustiyanti, 2017 : 1).

Staf Khusus Kemenko Kemaritiman Purbaya Sadewa mengatakan bahwa penurunan tingkat konsumsi pada produk perusahaan ritel ini bukan hanya diakibatkan karena munculnya ritel online, tetapi banyak faktor lain yang mempengaruhi. Hasil survei yang dilakukan oleh Nielsen pun menunjukkan pangsa pasar online untuk Fast Moving Consumer Good (FMCG) hanya 1\% dari total penjualan ritel yang nilainya berkisar Rp 450 triliun pada tahun 2016. Hal ini menjelaskan bahwa ritel online bukan yang mempengaruhi secara besar penurunan konsumsi di masyarakat (Fau, Rizal, Harini dan Rachman, $2017: 1$ ).

Faisal Basri (2017) mengatakan bahwa penurunan konsumsi ritel diakibatkan adanya pergeseran atau shifting pola konsumsi dari kebutuhan non-leisure ke leisure. Kegiatan non-leisure meliputi makanan dan pakaian sedangkan leisure meliputi hospitality (hotel dan restoran) serta rekreasi dan budaya (Basri, $2017: 1$ ).

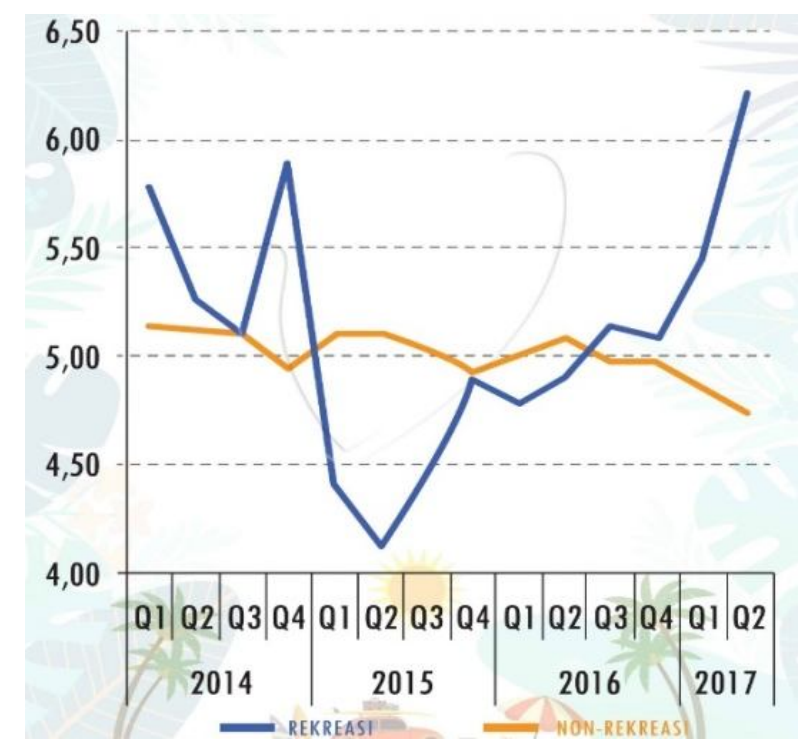

Gambar 1.1 Pergeseran Leisure Economy

Sumber : (Sindonews.com, 2017)

Gambar 1 menunjukkan bahwa terdapat pergerakan konsumsi dari non-leisure menjadi leisure. Dimana kurva untuk sektor rekreasi meningkat dari tahun 2015 hingga 2017 di kuartal 2 sedangkan untuk sektor non rekreasi kurva stabil cenderung menurun di tahun 2017. 
Pergeseran pola pikir diantara para milenial juga berpengaruh, di mana mereka mengartikan kebahagiaan bukan berfokus pada posisi atau status karir. Berdasarkan Everbite-Harris Poll, generasi milenium mengartikan kebahagiaan tidak terfokus pada kepemilikan atau status karir tetapi hidup yang bermakna, hidup yang bahagia adalah tentang menciptakan, berbagi, dan menangkap berbagai kenangan yang diperoleh melalui pengalaman (Milenial Jaman Now "Penggerak Leisure Economy", $2017: 1$ ).

Berdasarkan hasil dari Nielsen Millenial Travellers Study, menyatakan bahwa anak muda memiliki kecenderungan untuk travelling lebih sedikit karena mereka berada di awal-awal karir dan mereka tidak mempunyai cukup waktu untuk berlibur namun faktanya dibandingkan dengan generasi lainnya, generasi muda lebih berkemungkinan melakukan perjalanan lebih banyak karena pendapatan dan keuangan mereka tumbuh (Milenial Jaman Now "Penggerak Leisure Economy", 2017 :1).

Generasi muda saat ini mengukur sebuah kebahagiaan bukan lagi dengan kepemilikan akan sesuatu melainkan pengalaman dan memamerkannya kepada orang disekitar. Hal ini dikarenakan konsumen milenial adalah konsumen yang paling haus dengan pengalaman (experience) (Yuswohady, $2017: 1$ ).

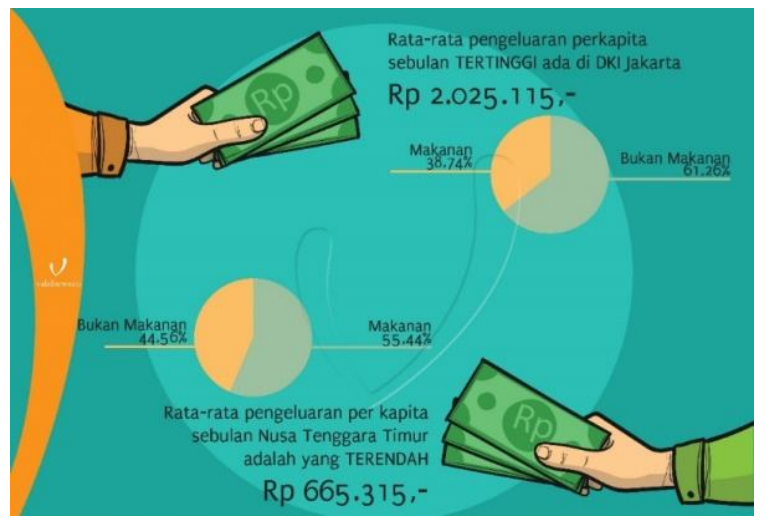

Gambar 2 Laporan Pengeluaran serta Konsumsi Penduduk Indonesia 2010

Sumber: Badan Pusat Statistik (bps.go.id)

Berdasarkan Gambar 2 dapat diketahui bahwa pengeluaran konsumsi masyarakat di perkotaan dan desa memiliki perbedaan. Dengan adanya perbedaan tingkat konsumsi menunjukkan bahwa shifting pola konsumsi lebih besar berkemungkinan terjadi pada masyarakat perkotaan besar seperti Jakarta. Lebih besarnya konsumsi bukan makanan di Jakarta menunjukkan bahwa masyakarat daerah Jakarta merupakan penggerak leisure economy yang lebih memilih untuk menggunakan pendapatan yang mereka miliki pada konsumsi di kegiatan leisure dibandingkan non-leisure. Dan tanpa sadar mereka menjadikan leisure dan pengalaman menjadi sebuah kebutuhan pokok yang harus dipenuhi (Yuswohady, $2017: 1$ ).

Dalam proses pemenuhan kebutuhan tersebut, akan dipengaruhi oleh kondisi sosial sekitar yang akhirnya akan menimbulkan suatu pola gaya hidup baru yang secara pasti akan mempengaruhi kehidupan. Mowen dan Michael (2008 : 117) mendefinisikan bahwa gaya hidup akan mempengaruhi perilaku seseorang yang pada akhirnya menentukan pola konsumsi seseorang.

Dengan adanya gaya hidup baru di masyarakat maka tidak sedikit generasi muda sebagai mesin pendorong leisure economy berusaha memenuhi kebutuhan leisure dan pengalaman tersebut sehingga mengesampingkan kebutuhan dasar lainnya. Hal ini dikarenakan bertambahnya jumlah pengeluaran yang harus dikeluarkan namun tidak diikuti dengan kenaikan jumlah pendapatan yang diperoleh (Yushita, 2017 : 14). 
Tabel 1. Perkembangan Transaksi Kartu Kredit

\begin{tabular}{llllll}
\hline & $\mathbf{2 0 1 2}$ & $\mathbf{2 0 1 3}$ & $\mathbf{2 0 1 4}$ & $\mathbf{2 0 1 5}$ & $\mathbf{2 0 1 6}$ \\
\hline \multirow{3}{*}{ Transaksi Secara Nominal } & $\mathrm{Rp}$ & $\mathrm{Rp}$ & $\mathrm{Rp}$ & $\mathrm{Rp}$ & $\mathrm{Rp}$ \\
& 201,8 & 223,3 & 255 & 280 & 281 \\
& triliun & triliun & triliun & triliun & triliun \\
\hline \multirow{3}{*}{ Volume Transaksi } & $\mathrm{Rp}$ & $\mathrm{Rp}$ & $\mathrm{Rp}$ & $\mathrm{Rp}$ & $\mathrm{Rp}$ \\
& 221 & 239 & 254 & 281 & 305 \\
& miliar & miliar & miliar & miliar & miliar \\
\hline
\end{tabular}

Sumber : CNB Indonesia (www.cnbindonesia.com)

Berdasarkan data tersebut, dapat diketahui bahwa dalam 5 tahun terakhir transaksi kartu kredit di Indonesia mengalami peningkatan setiap tahunnya. Meningkatnya jumlah transaksi kartu kredit dapat mengindikasikan adanya kebiasaan masyarakat dalam melakukan transaksi dan pengelolaan keuangannya. Penggunaan yang mudah dapat mendorong masyarakat untuk bersikap konsumtif dengan membelanjakan uang tanpa adanya perhitungan. Permasalahan yang sering muncul dengan sikap ini adalah ketidakmampuan mereka dalam memenuhi kebutuhan wajib mereka karena adanya kenaikan pengeluaran yang harus mereka keluarkan dan juga tidak adanya pengelolaan keuangan yang baik. Maka dari itu pengelolaan keuangan idealnya dilakukan sejak dini karena dapat meminimalisir kemungkinan ketidak bertanggungjawaban seseorang terhadap keuangannya. Rendahnya kegiatan menabung, investasi ataupun perencanaan keuangan menjadi permasalahan yang sering muncul di masyarakat.

Menurut Yushita (2017 : 14) menyatakan bahwa pengelolaan keuangan pribadi merupakan salah satu kompetensi yang paling mendasar yang dibutuhkan oleh masyarakat modern karena pilihan konsumen dari hari ke hari akan mempengaruhi keamanan keuangan dan standar hidup seseorang. Kesulitan keuangan dapat muncul jika terjadi kesalahan dalam pengelolaan keuangan (Yushita, $2017:$ 13).

Pengelolaan keuangan erat kaitannya dengan tingkat literasi keuangan. Pengelolaan keuangan yang tepat dan ditunjang dengan literasi keuangan yang baik maka taraf hidup masyarakat diharapkan akan meningkat, karena walau bagaimanapun tingginya tingkat penghasilan seseorang tapi tanpa pengelolaan keuangan yang tepat, keamanan finansial pasti akan sulit tercapai.

Yushita (2017 : 13) mengatakan bahwa literasi keuangan merupakan kebutuhan dasar bagi setiap orang agar terhindar dari masalah keuangan. Dengan tingginya tingkat literasi keuangan pada suatu masyarakat diharapkan mereka akan mampu menikmat hidup dengan sumber daya keuangan yang dimiliki dengan tepat.

Tabel 2 Indeks Literasi Keuangan Penduduk Indonesia tahun 2013

\begin{tabular}{ll}
\hline Indeks Literasi Keuangan & $\%$ \\
\hline Well Literate & 21.48 \\
\hline Sufficient Literate & 75.69 \\
\hline Less Literate & 2.06 \\
\hline Not Literate & 0.41 \\
\hline & 100
\end{tabular}

Sumber : Otoritas Jasa Keuangan (www.ojk.go.id)

Berdasarkan data dari Tabel 2 diketahui bahwa masyarakat Indonesia yang tergolong well literate sebanyak $21.48 \%$, sufficient literate sebanyak $75.69 \%$, less literate sebanyak $2.06 \%$ dan not literate 0.41\%. Dalam survey Nasional Literasi dan Inklusi Keuangan (Otoritas Jasa Keuangan, 2016) menjelaskan bahwa sikap keuangan masyarakat terkait tujuan keuangan yaitu masyarakat Indonesia masih didominasi dengan tujuan jangka pendek untuk memenuhi kehidupan sehari-hari dan 
AKURASI, 1(1), 31 - 42

Nurul Amalia Putri \& Diyan Lestari. Pengaruh Gaya Hidup dan Literasi Keuangan ...

mempertahankan hidup dibandingkan dengan perencanaan untuk masa depan, seperti yang dijelaskan dalam Tabel 3.

Tabel 3 Sikap Keuangan Masyarakat Terkait Tujuan Keuangan

\begin{tabular}{lll}
\hline MEMENUHI KEBUTUHAN & BERTAHAN & BIAYA \\
SEHARI-HARI & HIDUP & PENDIDIKAN \\
\hline $49.11 \%$ & $17.68 \%$ & $8.00 \%$ \\
\hline
\end{tabular}

Sumber : Otoritas Jasa Keuangan (www.ojk.go.id)

Dalam hasil Survey Nasional Literasi dan Inklusi Keuangan (Otoritas Jasa Keuangan, 2016) untuk mencapai tujuan keuangan, upaya utama yang dipilih oleh masyarakat cenderung berupa upaya jangka pendek yang sejalan dengan kecenderungan tujuan keuangannya, seperti yang dijelaskan dalam Tabel 1.4 (Otoritas Jasa Keuangan, 2016).

Tabel 4 Perilaku Keuangan Masyarakat Dalam Mencapai Tujuan Keuangan

\begin{tabular}{lll}
\hline \multirow{2}{*}{ MENABUNG } & MENYUSUN & BEKERJA / \\
& RENCANA & MENCARI \\
& KEUANGAN & PEKERJAAN \\
\hline $75.29 \%$ & $42.13 \%$ & $38.36 \%$ \\
\hline \multicolumn{2}{l}{ Sumber : Otoritas Jasa Keuangan (www.ojk.go.id) }
\end{tabular}

Kegiatan menabung menjadi cara yang paling banyak dipilih oleh masyarakat untuk mencapai tujuan keuangan dibandingkan dengan menyusun rencana keuangan, bekerja atau mencari pekerjaan dan investasi. Hasil ini berkaitan dengan survei sebelumnya yang mengatakan bahwa masyarakat Indonesia masih didominasi dengan kegiatan perencanaan keuangan jangka pendek yang salah satu cara dilakukannya dengan melalui tabungan.

Pengetahuan keuangan yang baik secara subjektif dan objektif berpengaruh terhadap perilaku keuangan secara signfikan dan pengetahuan keuangan merupakan prediktor utama dalam membentuk perilaku keuangan (Universitas Pendidikan Undikhsha, 2015 : 67). Kemampuan seseorang dalam melakukan perencanaan, pengelolaan serta pengendalian keuangan erat kaitannya dengan pengetahuan seseorang tersebut terhadap konsep literasi keuangan.

Masyarakat dengan latar belakang pengetahuan keuangan yang baik akan sadar dan lebih mementingkan proritas. Namun tidak menutup kemungkinan jika masyarakat dengan tingkat pendidikan yang tinggi dan kondisi finansial yang mapan akan membelanjakan uangnya secara berlebihan tanpa adanya perhitungan dengan baik karena mereka terdesak dengan gaya hidup yang ada pada lingkungannya. Rendahnya tingkat literasi keuangan masyarakat juga menjadi penyebab tidak berjalan dengan baik sebuah pengelolaan keuangan. Literasi keuangan menjadi sangat penting karena merupakan sebuah landasan kritis bagi seseorang untuk pengambilan keputusan pembelian sesuatu. Berdasarkan fenomena dan juga penelitian-penelitian yang mendukung dan menolak seperti diuraikan di atas, maka peneliti tertarik untuk melakukan penelitian dengan judul : "Pengaruh Gaya Hidup Dan Literasi Keuangan Terhadap Pengelolaan Keuangan Tenaga Kerja Muda Di Jakarta”.

\section{KAJIAN PUSTAKA DAN MODEL PENELITIAN}

Gaya Hidup

Menurut Sugihartati (2010 : 159) gaya hidup adalah cara hidup mencakup sekumpulan kebiasaan, pandangan dan pola-pola respon terhadap hidup, serta terutama perlengkapan untuk hidup. Gaya hidup juga merupakan cara bagaimana seseorang hidup, termasuk bagaimana seseorang 
menggunakan uangnya, bagaimana ia mengalokasikan waktunya dan sebagainya (Kanserina, 2015 : 3).

Sunarto (2003 : 103) gaya hidup adalah pola kehidupan seseorang untuk memahami kekuatan-kekuatan ini kita harus mengukur dimensi AIO utama konsumen aktivitas (pekerjaan, hobi, belanja, olahraga, kegiatan sosial), minat (makanan, mode, keluarga, rekreasi), pendapat (mengenai diri mereka sendiri, masalah-masalah sosial, bisnis, produk). Berikut penjelasan mengenai dimensi gaya hidup :

Activities, merupakan adalah apa yang dikerjakan konsumen, produk apa yang dibeli ataupun digunakan, kegiatan apa yang dilakukan untuk mengisi waktu luang. Contoh aktivitas yaitu : menghabiskan waktu luang untuk liburan keluar kota, menggunakan produk eco friendly, menggunakan gadget dalam kehidupan sehari-hari. Interest / minat adalah akan semacam obyek, peristiwa, atau topik adalah tingkat kegairahan yang menyertai perhatian khusus maupun terusmenerus kepadanya. Di dalamnya juga termasuk kesukaan, kegemaran dan prioritas dalam hidup konsumen. Contoh minat yaitu : tertarik untuk membeli suatu produk karena promosi. Opinion / pendapat adalah pandangan dan perasaan konsumen dalam menanggapi isu-isu global, lokal, moral, ekonomi dan sosial. Opini digunakan untuk mendeskripsikan penafsiran, harapan dan evaluasi seperti kepercayaan mengenai maksud orang lain, antisipasi sehubungan dengan peristiwa masa datang, dan penimbangan konsekuensi yang memberi ganjaran atau menghukum dari jalannya tindakan alternatif. Contoh opini : menganggap merek adalah suatu hal penting dari sebuah produk.

\section{Literasi Keuangan}

Literasi keuangan dapat diartikan sebagai pengetahuan keuangan yang bertujuan untuk mencapai kesejahteraan, didefinisikan oleh Lusardi \& Mitchell (2014 : 2). Menurut Yushita (2017 : 16) literasi keuangan adalah kemampuan yang mencakup untuk membedakan pilihan keuangan, membahas uang dan masalah keuangan tanpa ketidaknyamanan, merencanakan masa depan, dan menanggapi kompeten untuk peristiwa kehidupan yang mempengaruhi keputusan keuangan sehari-hari, termasuk peristiwa di ekonomi secara umum.

Menurut Chen \& Volpe (1998 : 110) terdapat empat dimensi literasi keuangan, yaitu : (1) Pengetahuan tentang keuangan mencakup pengetahuan keuangan pribadi yakni bagaimana mengatur pendapatan dan pengeluaran serta memahami konsep dasar keuangan; (2) Tabungan merupakan simpanan uang di bank yang penarikannya hanya dapat dilakukan menurut syarat tertentu (Otoritas Jasa Keuangan, 2016); (3) Asuransi adalah perjanjian antara dua pihak, yaitu perusahaan asuransi dan pemegang polis, yang menjadi dasar bagi penerimaan premi oleh perusahaan asuransi (Undang-undang No. 40, 2014); (4) Investasi merupakan komitmen saat ini terhadap uang atau sumber daya lainnya dengan harapan dapat menuai keuntungan masa depan. (Bodie, Kane, \& Marcus, 2008 : 1)

\section{Pengelolaan Keuangan}

Pengelolaan keuangan merupakan bagian dari kegiatan manajemen keuangan pribadi yang merupakan proses seorang individu memenuhi kebutuan hidup melalui kegiatan mengelola sumber keuangan secara tersusun dan sistematis. Sina (2012 : 172-173) menjelaskan bahwa pengalaman keuangan merupakan kemampuan membuat suatu pertimbangan atau melakukan investasi di masa depan. Dengan perencanaan dan pengelolaan investasi yang baik dan benar akan mencapai ketentraman dan kenyamanan dalam hidup (Yulianti \& Silvy, 2013 : 60).

Mental Accounting Theory dan Prospect Theory

Mental accounting theory merupakan deskripsi mengenai cara seseorang melakukan proses akuntansi yang hanya dapat dipelajari dengan melakukan pengamatan mengenai perilaku seseorang atau menyimpulkan kaidah-kaidah yang berlaku di masyarakat (Silaya \& Persulessy, 2017 : 59). 
Menurut Bodie, Kane dan Marcus (2008 : 388) prospect theory memodifikasi deskripsi analitik dari investor risk averse rasional yang ditemukan dalam teori keuangan standar. Dalam hal ini prospect theory berhubungan dengan sikap pengambilan keputusan seseorang yang tidak hanya berdasarkan pertimbangan rasional tetapi aspek emosional juga berpengaruh di dalamnya. Dalam kondisi ketidakpastian individu akan memutuskan berdasarkan pertimbangan untung dan rugi. Pembuatan keputusan dalam kondisi ketidakpastian ini disebut dengan prospect theory. Keputusan tersebut dapat berubah jika terpaksa harus merubahanya karena dalam prospect theory akan mempertimbangkan titik referensi dari segala sudut.

Model Penelitian

Penelitian ini menganalisis hubungan antara gaya hidup dan literasi keuangan terhadap pengelolaan keuangan. Metode Analisis yang digunakan adalah regresi linier berganda. Model konseptual dapat dilihat pada Gambar 2.

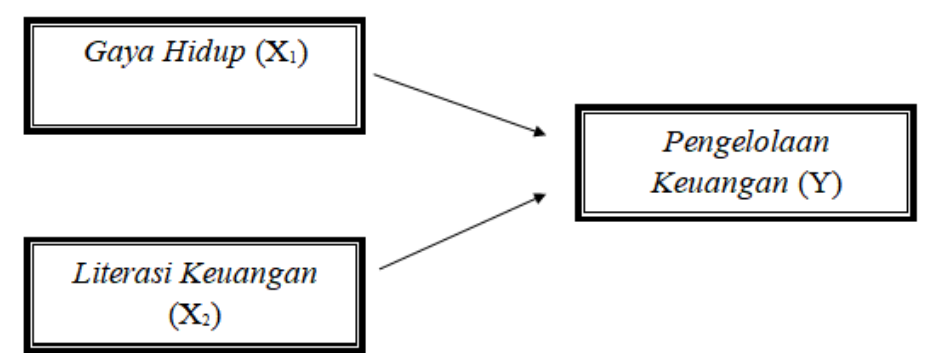

Gambar 3. Model Konseptual Penelitian

Gaya hidup dan literasi keuangan diteliti sebagai variabel independen dan pengelolaan keuangan diteliti sebagai variabel dependen.

\section{METODE PENELITIAN}

Prosedur Pengambilan Data

Sumber data yang digunakan dalam penelitian ini adalah sumber data primer dengan metode pengumpulan data menggunakan kuesioner. Penelitian ini menggunakan model pengukuran skala likert. Menurut Syofian (2015 : 50) skala likert adalah skala yang dapat digunakan untuk mengukur sikap, pendapat dan persepsi seseorang tentang suatu objek atau fenomena tertentu. Subjek penelitian ini adalah tenaga kerja muda di Jakarta. Sebelum diisi oleh responden kuesioner terlebih dahulu diuji tingkat validitas, reliabilitas dan normalitasnya. Setelah valid, reliabel dan normal maka kuesioner dapat diisi oleh responden dan dilakukan uji asumsi klasik, uji regresi linier berganda,uji t, uji F dan uji koefisien determinasi.

Jakarta dipilih sebagai populasi dari penelitian karena berdasarkan survey Badan Pusat Statistik tahun 2010 rata-rata pengeluaran perkapita tertinggi selama sebulan diperoleh Jakarta dengan persentase 61,26\% pengeluaran untuk konsumsi bukan makanan (leisure) sedangkan 38,74\% merupakan pengeluaran konsumsi makanan (non-leisure). Dengan lebih besarnya pengeluaran konsumsi bukan makanan (leisure) menunjukkan bahwa shifting pola konsumsi lebih besar berkemungkinan terjadi pada masyarakat perkotaan besar seperti Jakarta. Sehingga Jakarta dapat mewakili sampel penelitian yang dapat memberikan data tentang gaya hidup, literasi keuangan dan pengelolaan keuangan dengan usia tenaga kerja muda yaitu 17 - 35 tahun. 
Teknik Analisis

Analisis Regresi Linier Berganda

Regresi linear berganda merupakan alat yang dapat digunakan untuk melakukan prediksi permintaan di masa yang akan datang, berdasarkan data masa lalu atau untuk mengetahui pengaruh satu atau lebih variabel bebas (independent) terhadap satu variabel tak bebas atau (dependent) (Siregar, 2015 : 405). Persamaan umumnya adalah :

$\begin{array}{ll} & \mathrm{PK}=\mathrm{a}+\mathrm{b} 1 \mathrm{GH}+\mathrm{b} 2 \mathrm{LK}+\mathrm{e} \\ \mathrm{PK} & =\text { Pengelolaan keuangan } \\ \mathrm{GH} & =\text { Gaya hidup } \\ \mathrm{LK} & =\text { Literasi keuangan } \\ \mathrm{a} & =\text { konstanta } \\ \mathrm{b} 1, \mathrm{~b} 2 & =\text { koefisien } \\ \mathrm{e} & =\text { error }\end{array}$

Uji t

Uji t bertujuan untuk mengetahui pengaruh variabel independen secara parsial terhadap variabel dependen (Priyatno, 2008 : 50). Pengujian dilakukan dengan membandingkan $t_{\text {hitung }}$ dengan $t_{\text {tabel }}$ atau dengan melihat kolom signfikansi pada masing-masing thitung. Pengambilan keputusannya adalah sebagai berikut :

a) Apabila $t_{\text {hitung }}>t_{\text {tabe, }}$ maka variabel independen berpengaruh terhadap variabel dependen.

b) Apabila thitung $<t_{\text {tabel, }}$ maka variabel independen tidak berpengaruh terhadap variabel dependen.

\section{Uji F}

Uji F bertujuan untuk mengetahui pengaruh variabel independen secara simultan atau bersamasama terhadap variabel dependen (Priyatno, 2008 : 51). Pengujian dilakukan dengan membandingkan $F_{\text {hitung }}$ dengan $F_{\text {tabel }}$ atau dengan melihat kolom signifikansi pada masing-masing

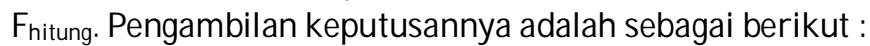

a) Apabila $F_{\text {hitung }}>F_{\text {tabel, }}$ maka variabel independen secara simultan berpengaruh terhadap variabel dependen.

b) Apabila $\mathrm{F}_{\text {hitung }}<\mathrm{F}$ tabel, maka variabel independen secara simultan tidak berpengaruh terhadap variabel dependen.

Uji Koefisien Determinasi ( $\left.\mathrm{R}^{2}\right)$

Uji determinasi atau $\mathrm{R}$ square digunakan untuk mengetahui seberapa besar pengaruh variabel independen terhadap variabel dependen. Menurut Priyatno (2008 : 79), analisis determinasi dalam regresi linear berganda digunakan untuk mengetahui persentase sumbangan pengaruh variabel independen $\left(\mathrm{X}_{1}, \mathrm{X}_{2}\right.$..) secara serentak terhadap variabel dependen.

\section{HASIL DAN PEMBAHASAN}

Uji Asumsi Klasik

Penelitian ini menggunakan metode Kolmogorov-Smirnov yang membandingkan frekuensi kumulatif distribusi teoritik dengan frekuensi kumulatif distribusi empirik atau observasi (Siregar, 2015 : 153). Data dinyatakan berdistribusi normal bila nilai signifikansi lebih dari 0,05. 
AKURASI, 1(1), 31 - 42

Nurul Amalia Putri \& Diyan Lestari. Pengaruh Gaya Hidup dan Literasi Keuangan ...

Tabel 5. Hasil Uji Normalitas Pre-test

\section{One-Sample Kolmogorov-Smirnov Test}

Asymp. Sig. (2-tailed) $\quad, 200^{\mathrm{c}, \mathrm{d}}$

Berdasarkan Tabel 5 melalui hasil One - Sample Kolmogorov - Smirnov Test diketahui bahwa nilai signifikansi (Asymp.Sig 2-tailed) sebesar 0,200 lebih besar dari 0,05. Sehingga dapat ditarik kesimpulan bahwa instrumen atau kuesioner untuk pre-test dari variabel gaya hidup, literasi keuangan dan pengelolaan keuangan nilai residualnya terdistribusi dengan normal.

Uji multikolinearitas digunakan untuk menguji apakah ditemukan adanya korelasi yang tinggi antar variabel independen. Metode pengujian dilakukan dengan melihat nilai inflation factor (VIF) dan tolerance pada model regresi. Jika nilai VIF kurang dari 10 dan tolerance lebih dari 0.1 maka model regresi tersebut bebas dari multikolinearitas (Priyatno, $2016: 116$ ).

Tabel 6 Hasil Uji Multikolinearitas

\begin{tabular}{lll}
\hline & \multicolumn{2}{l}{ Collinearity Statistics } \\
\hline & Tolerance & VIF \\
\hline GH & 0,778 & 1,285 \\
\hline LK & 0,778 & 1,285 \\
\hline
\end{tabular}

Berdasarkan Tabel 6 melalui hasil uji multikolinearitas dengan melihat nilai tolerance dan inflation factor (VIF) pada model regresi diketahui bahwa nilai tolerance kedua variabel lebih dari 0,10 yaitu 0,778 dan nilai VIF kurang dari 10 yaitu 1,285. Sehingga dapat ditarik kesimpulan bahwa tidak terjadi multikolinearitas antarvariabel bebas.

Uji heteroskedastisitas dilakukan untuk menguji ketidaksamaan varian dari residual pada satu pengamatan ke pengamatan lain. Model regresi yang memenuhi persyaratan adalah dimana terdapat kesamaan varians dari residual satu pengamatan ke pengamatan yang lain tetap atau disebut homoskedastisitas. Metode yang digunakan dalam uji heteroskedastisitas adalah Glejser.

Tabel 7 Hasil Uji Heteroskedastisitas

\begin{tabular}{l|l}
\multicolumn{2}{c}{ Coefficients } \\
\hline \multicolumn{2}{c}{ Sig } \\
\hline GH & 0,531 \\
\hline LK & 0,309 \\
\hline
\end{tabular}

Berdasarkan Tabel 7 melalui hasil uji heteroskedastisitas diketahui bahwa nilai signifikansi kedua variabel independen lebih dari 0,05 yaitu GH dengan nilai 0,531 dan LK dengan nilai 0,309. dengan demikian dapat disimpulkan bahwa tidak terjadi masalah heteroskedastisitas pada model regresi.

Analisis Regresi

Analisis regresi linear berganda dilakukan untuk memprediksi besaran pengaruh antara variabel bebas (GH dan $\mathrm{LK}$ ) terhadap variabel pengelolaan keuangan (PK). Hasil analisis regresi linear berganda dapat dilihat pada Tabel berikut : 
Tabel 8. Hasil Analisis Regresi Linier Berganda

\begin{tabular}{lllll}
\hline & Koefisien & $\mathbf{t}_{\text {hitung }}$ & Sign & Hasil \\
\hline Constant & 5,910 & & & \\
GH & 0,369 & 5,49 & 0,000 & Diterima \\
LK & 0,260 & 4,889 & 0,000 & Diterima \\
\hline F-Statistics & 50.985 & & & \\
Sig. F statistics & $.000^{\mathrm{b}}$ & & & \\
R & $.660^{\mathrm{a}}$ & & & \\
Adj. R Square & .427 & & & \\
\hline
\end{tabular}

Berdasarkan Tabel 8, maka persamaan regresi linear berganda dapat dibaca sebagai berikut:

\section{$P K=5,910+0,369(G H)+0,260(L K)+e$}

Nilai konstanta yang didapat adalah sebesar 5,910, artinya jika gaya hidup (GH) dan literasi keuangan (LK) nilainya adalah 0, maka pengelolaan keuangan memiliki nilai sebesar 5,910. Koefisien regresi variabel gaya hidup (GH) sebesar 0,369, artinya jika variabel independen lainnya bernilai tetap dan gaya hidup (GH) mengalami kenaikan sebesar 1 tingkat, maka pengelolaan keuangan (PK) akan mengalami kenaikan sebesar 0,369 atau 36,9\%. Koefisien regresi variabel literasi keuangan (LK) sebesar 0,260, artinya jika variabel independen lainnya bernilai tetap dan literasi keuangan (LK) mengalami kenaikan sebesar 1 tingkat, maka pengelolaan keuangan (PK) akan mengalami kenaikan sebesar 0,260 atau $26 \%$.

Uji t dilakukan untuk melihat bagaimanakah pengaruh masing-masing variabel independennya secara masing-masing terhadap variabel dependennya. Variabel gaya hidup (GH) nilai $t_{\text {hitung }}>t t_{\text {abel }}$ $(5,490>1,97810)$ dan signifikansi $<0,05(0,000<0,05)$ maka dapat disimpulkan bahwa gaya hidup (GH) secara parsial berpengaruh terhadap pengelolaan keuangan. Sedangkan untuk variabel literasi keuangan (LK) nilai $t_{\text {hitung }}>\mathrm{t}_{\text {tabel }}(4,889>1,97810)$ dan signifikansi $<0,05(0.000<0,05)$ maka dapat disimpulkan bahwa literasi keuangan $\left(\mathrm{X}_{2}\right)$ secara parsial berpengaruh terhadap pengelolaan keuangan.

Berdasarkan Tabel 8 diatas melalui hasil uji F diketahui bahwa nilai F hitung $>$ F tabel $(50,985$ $>3,06$ ) yang berarti bahwa gaya hidup dan literasi keuangan secara simultan berpengaruh terhadap pengelolaan keuangan. Dan nilai signifikansinya sebesar 0,000 <0,05.

Uji $\mathrm{R}^{2}$ (koefisien determinasi) dilakukan untuk mengetahui persentase sumbangan pengaruh variabel independen terhadap variabel dependen. Berdasarkan Tabel 8 diatas melalui hasil uji $\mathrm{R}^{2}$ (koefisien determinasi) diketahui bahwa nilai $\mathrm{R}^{2}$ sebesar 0,436 yang berarti bahwa persentase sumbangan pengaruh variabel gaya hidup dan literasi keuangan terhadap pengelolaan keuangan sebesar $43,6 \%$.

\section{KESIMPULAN}

\section{Kesimpulan}

Simpulan yang dapat ditarik dari penelitian ini adalah : (1) gaya hidup berpengaruh secara parsial terhadap pengelolaan keuangan; (2) literasi keuangan berpengaruh secara parsial terhadap pengelolaan keuangan; (3) gaya hidup dan literasi keuangan berepngaruh secara simultan terhadap pengelolaan keuangan.

Implikasi

Berdasarkan hasil penelitian, maka perusahaan-perusahaan investasi ataupun lembaga perencanaan keuangan perlu memanfaatkan perkembangan teknologi untuk menyampaikan informasi-informasi yang berkaitan dengan literasi keuangan ataupun perencanaan keuangan pribadi agar dapat diterima 
dengan mudah oleh masyarakat dan membantu masyarakat dalam melakukan pengelolaan keuangan yang tepat, serta terus berupaya untuk menyampaikan informasi dan mendorong masyarakat mengenai pentingnya pemahaman pengetahuan keuangan dan mendorong gaya hidup yang sesuai dengan kemampuan masing-masing individu.

Keterbasan dan Saran

Berdasarkan hasil penelitian yang telah dilakukan terdapat beberapa keterbatasan dalam penelitian, antara lain variabel bebas yang diteliti terbatas hanya pada gaya hidup dan literasi keuangan. Peneliti selanjutnya disarankan untuk menggunakan variabel lainnya seperti pendapatan, lama bekerja, jabatan, ataupun tingkat pendidikan.

\section{REFERENSI}

Agustiyanti. (2017) Survey Nielsen Ungkap 'Biang Keladi' lesunya Ritel. [Online]. Diakses 17 Maret 2018 dari https:/ / m.cnnindonesia.com/

Asmara, C. G. (2018) Masyarakat Belanja Pakai Kartu Kredit Rp 297 T di 2017. [Online]. Diakses 13 Juni 2018 dari https:/ / www.cnbindonesia.com/

Basri, Faisal. (2017) Transformasi Struktural dan Daya Beli. [Online]. Diakses 17 Maret 2018 dari https:/ / faisalbasri.com/

Bodie, Kane, \& Marcus. (2008). Investments. Singapore: McGraw Hill International Edition.

Chen, H., \& Volpe. (1998). An Analysis of Personal Financial Literacy among College Students. Financial Services Review, hlm 107 - 128.

Fau, Teodora Nirmala., Rizal., Fin H., Faisal R. (2015). "Leisure Economy Antara Perubahan Konsumsi, Disrupsi dan Potensi". [Online]. Diakses 13 Juni 2018 dari https:/ / validnews.co/

Kanserina, D. (2015). "Pengaruh Literasi Ekonomi dan Gaya Hidup Terhadap Perilaku Konsumtif Mahasiswa Jurusan Pendidikan Ekonomi UNDIKSHA 2015". Jurnal Pendidikan Ekonomi UNDIKSHA. Vol.5, No. 1, hlm 1-10.

Lusardi, A., \& Mitchell. (2014). "The Economic Importance of Financial Literacy : Theory and Evidence". Journal of Economic Literature, hlm 5 - 44.

Malhotra, N. (2010). Marketing Research : An Applied Orientation 6th ed. New Jersey: Pearson Prentice Hall.

Mowen, J. C., \& Minor, M. (2008). Prinsip - Prinsip Pemasaran. Jakarta: Erlangga.

Nabilla, D. R. (2016). “Pengaruh Pengetahuan Keuangan, Pendapatan dan Gaya Hidup Terhadap Perilaku Pengelolaan Keuangan Profesional Muda di Surabaya”. Skripsi Sarjana Manajemen STIE PERBANAS, Surabaya.

Otoritas Jasa Keuangan. (2016) Survei Nasional Literasi dan Inklusi Keuangan. [Online]. Diakses 13 Juni 2018 https:/ / sikapiuangmu.ojk.go.id/

Otoritas Jasa Keuangan. (2016). Tabungan. [Online]. Diakses 13 Juni 2018 https:/ / sikapiuangmu.ojk.go.id/ FrontEnd/ CMS/ Category/ 120

Otoritas Jasa Keuangan. (2017) Pengelolaan Investasi. [Online]. Diakses 13 Juni 2018 http:/ / www.ojk.go.id/ id/ kanal/ pasar-modal/ Pages/ Pengelolaan-Investasi.aspx

Priyatno. (2008). SPSS Untuk Analisis Korelasi, Regresi dan Multivariate. Yogyakarta: Gava Media.

Priyatno, D. (2016). SPSS Handbook : Analisis Data, Olah Data dan Penyelesaian Kasus-Kasus Statistik. Yogyakarta: MediaKom.

Silaya, M. A., \& Persulessy, G. (2017). "Mental Accounting dan Faktor Demografi : Fenomena Penggunaan Kartu Kredit Pada Pegawai Bank Danamon Cabang Ambon". Jurnal SOSOQ, hlm 57 -67.

Sina, P. G. (2014). "Tipe Kepribadian dalam Personal Finance”. Jurnal JIBEKA, hlm 54 - 59.

Sina, P. G., \& Andris, Noya. (2012). "Pengaruh Kecerdasan Spiritual Terhadap Pengelolaan Keuangan Pribadi".Jurnal Manajemen, hlm 171-187.

Siregar. (2015). Statistik Parametrik Untuk Penelitian Kuantitatif . Jakarta: Bumi Aksara.

Siregar, S. (2013). Metode Penelitian Kuantitatif. Jakarta: Kencana. 
Siregar, S. (2015). Satistik Parametrik untuk Penelitian Kuantitatif. Jakarta: Bumi Aksara.

Sugihartati, R. (2010). Membaca, Gaya Hidup dan Kapitalisme. Yogyakarta: Graha Ilmu.

Sugiyono. (2012). Metode Penelitian Kuantitatif Kualitatif dan R\&B. Bandung: Alfabeta.

Sunarto.(2003). Pemasaran. Yogyakarta. BPFE UST.

Yulianti, N., \& Silvy, M. (2013). “Sikap Pengelolaan Keuangan dan Perilaku Perencanaan Investasi Keluarga di Surabaya". Journal of Business and Banking, 60.

Yushita, A. N. (2017). "Pentingnya Literasi Keuangan Bagi Pengelolaan Keuangan Pribadi”. Jurnal Nominal, 14.

Yuswohady. (2017). "Millenial Jaman Now : Penggerak Leisure Economy”. [Online]. Diakses 17 Juni 2018 dari https:// ekbis.sindonews.com/

Yuswohady. (2017). "Welcome Leisure Economy". [Online]. Diakses 17 Juni 2018 dari https:/ / www.yuswohady.com/ 2017/ 10/ 28/ welcome-leisure-economy/

\section{PROFIL PENULIS}

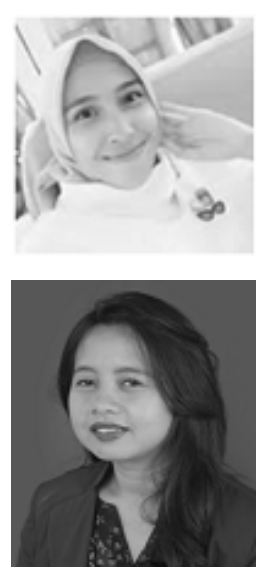

Nurul Amalia Putri. Mahasiswa jurusan manajemen Institut Teknologi dan Bisnis Kalbis, dengan konsentrasi jurusan manajemen keuangan. Penulis memiliki ketertarikan pada riset di bidang manajemen keuangan pribadi atau personal finance.

Diyan Lestari. Dosen jurusan manajemen Institut Teknologi dan Bisnis Kalbis, pengalaman mengajar sejak tahun 2014. Mengampu mata kuliah manajemen keuangan, manajemen risiko, manajemen keuangan pribadi, manajemen investasi dan portofolio, dan manajemen keuangan internasional. Penulis tertarik melakukan penelitian mengenai corporate finance dan personal finance. 